\title{
Effect of particle size on storage time of hydrated corn grain
}

\section{Efeito do tamanho de partícula associado ao tempo de armazenamento do milho moído reidratado}

\author{
Wilson Nei Zacaron ${ }^{1 *}$; Clovisnei Basi1'; Cintiamara Baggio '; Gabriela Solivo²; Liziane \\ Schittler Moroni ${ }^{3}$; Ana Luiza Bachmann Schogor ${ }^{4}$; Claiton André Zotti ${ }^{5}$
}

\section{Highlights}

Rehydrated corn grain silage stored for longer periods contains more soluble protein.

Rehydrated corn grain with smaller particles contains higher LAB and mold counts.

Rehydrated corn grain with smaller particles showed faster temperature increases.

Breaking aerobic stability is delayed with longer fermentation times.

\begin{abstract}
Dry ground corn kernels are widely used as sources of energy readily available for microbial synthesis in the rumen. The objective of the present study was to measure the effect of particle size on the storage length of rehydrated and ensiled corn grain. Commercial corn was milled in 2-, 4-, 6-, 8-, and 10-mm sieves, rehydrated until reaching $65 \% \mathrm{DM}$, and ensiled for 14,28 , and 56 days, in a completely randomized design with a $5 \times 3$ factorial arrangement, with six replications per treatment. PVC mini-silos were used, with dimensions of $25 \mathrm{~cm}$ height $x 10 \mathrm{~cm}$ of diameter. The variables DM, MM, CP, NDF, ADF, pH, molds and yeasts count, fermentative losses, in vitro degradability and aerobic stability were subjected to analysis of variance. The Tukey test was used to compare means. LAB counts was subjected to Wilcoxon's nonparametric test, considering significance at $p<0.05$. Rehydrated corn silages with smaller particles $(2$ and $4 \mathrm{~mm}$ ) showed higher LAB and mold counts, higher levels of CP and EE and higher density at opening silos than that of coarser particles. However, they showed lower percentages of DM, and were susceptible to microbial attack and faster temperature increases than were coarse particles during the chosen storage times. Silage subjected to 56 days of fermentation showed lower contents of NDF, ADF and CP, lower gas losses and lower $\mathrm{pH}$ values in aerobiosis, and increased levels of soluble protein ( $+\mathrm{B} 1$ fractions), losses by

1 Students of the Postgraduate Program in Animal Health and Production, Universidade do Oeste de Santa Catarina, UNOESC, Xanxerê, SC, Brazil. E-mail: wilson.zacaron@unoesc.edu.br; clovisbasizootecnista@outlook.com; cintiamara.baggio@unoesc.edu.br

2 Student of Animal Science, UNOESC, Xanxerê, SC, Brazil. E-mail: gabriellasolivo@gmail.com

3 Prof. Dr., Department of Microbiology, UDESC, Pinhalzinho, SC, Brazil. E-mail: liziane.schittler@udesc.br

4 Prof. Dr., Postgraduate Program in Animal Science, UDESC, Chapecó, SC, Brazil. E-mail: ana.schogor@udesc.br

5 Prof. Dr., Postgraduate Program in Animal Health and Production, UNOESC, Xanxerê, SC, Brazil. E-mail: claiton.zotti@ unoesc.edu.br

* Author for correspondence
\end{abstract}

Received: Apr. 23, 2020 - Approved: Dec. 04, 2020 
effluents, number of hours to reach maximum temperature, and time to break aerobic stability. Coarse-grind silages subjected to 56 days of storage showed better chemical composition, lower LAB and mold counts, and less susceptibility to microbial degradation when exposed to air.

Key words: Granulometry. Fermentation time. Microbiology. Deterioration.

\section{Resumo}

O milho moído seco é um dos ingredientes mais utilizados como fonte de energia rapidamente disponível para a síntese microbiana no rúmen. Objetivou-se avaliar o efeito do tamanho de partícula associada ao tempo de armazenamento sobre o milho moído reidratado e ensilado. Foi realizada a moagem de milho comercial em peneiras de 2, 4, 6, 8 e $10 \mathrm{~mm}$, reidratado até atingir $65 \%$ de MS e ensilado por 14, 28 e 56 dias, num delineamento inteiramente casualizado em arranjo fatorial $5 \times 3$, com seis repetições por tratamento. Foram utilizados mini-silos de PVC, de dimensões $25 \mathrm{~cm}$ altura $\times 10 \mathrm{~cm}$ diâmetro. Os dados referentes às variáveis $\mathrm{MS}, \mathrm{MM}, \mathrm{PB}, \mathrm{FDN}, \mathrm{FDA}, \mathrm{pH}$, contagem de bolores e leveduras, perdas fermentativas, degradabilidade in vitro e estabilidade aeróbia foram submetidas à análise de variância e o teste Tukey para comparação de médias, e a contagem de BAL foi submetida ao teste não-paramétrico de Wilcoxon, ambos considerando significância 5\%. Silagens de grãos milho reidratados com partículas menores (2 e $4 \mathrm{~mm}$ ) apresentaram maiores contagens de BAL e bolores, teores mais elevados de PB, EE e maior massa específica na abertura dos silos em relação às partículas mais grossas. Porém, demonstraram menores percentuais de MS, e foram passíveis de ataque microbiano e elevação de temperatura mais rapidamente do que partículas grossas durante os tempos de armazenamento avaliados. Silagens armazenadas por 56 dias apresentaram menores teores de FDN, FDA e PB, menores perdas por gases e menores valores de pH em aerobiose, e aumentaram a proteína solúvel (frações $A+B 1$ ), as perdas por efluentes e o tempo para quebra da estabilidade aeróbia das silagens. Silagens com moagem grossa e submetidas a 56 dias de armazenamento apresentaram melhor composição bromatológica, menores contagens de BAL e bolores, e menor susceptibilidade à degradação microbiana quando expostas ao ar.

Palavras-chave: Granulometria. Tempo de armazenamento. Microbiologia. Deterioração.

\section{Introduction}

One substantial challenge of modern cattle farming is maximization of the use of nutrients present in feed so as to generate greater productivity and, subsequently, greater profits for the farmers. Dry ground corn kernels are among the most widely used sources of energy for microbial production in the rumen. When corn grain is given in whole or coarse particles, the rumen microbiota uses the starch with less fermentative potential (Owens, 2015). We are seeking alternatives that make it possible to increase the use of this nutrient by ruminal microorganisms, converting it into microbial protein and short-chain fatty acids.

One of the easiest and lowest-cost ways to optimize the use of corn starch by microorganisms is to mechanically grind or break the grains using hammers or blades (Bitencourt, 2012). This process allows the destructuring of prolamines, i.e., proteins responsible for the protection of the endosperm that are present in a dense protein matrix. Without breaking this matrix, the degree of enzymatic starch digestion depends on the resistance of structural carbohydrates 
and protein barriers to microbial digestion (McAllister, Rode, Major, Cheng, \& Smith, 1990).

In addition to the simple breaking of the grain, fermentation through silage is used to increase amidic availability (Rezende et al., 2014). In this process, in addition to the breakdown of prolamines (also called zeins) gelatinization of the starch also occurs by breaking the structure of crystals that compose the matrix forming the starch granules, and this increases its solubility, according Denardin and Silva (2009).

To reduce labor, time, and energy costs, many farms use whole grain or coarse grind, rather than grinding into fine particles to create moist or rehydrated corn silage. Doing this can compromise digestibility ruminal starch, because smaller particles maximize the available surface area for microbial fixation and subsequent degradation (Saylor, Casale, Sultana, \& Ferraretto, 2019); however, compensation occurs in the form of starch digestibility in the small intestine. According to these authors, there is usually a need to start using silage to feed animals in periods not exceeding 30 days of storage, and this also compromises the availability of starch.

Studies have evaluated the variability of rehydrated corn silage particle size, from finer to coarser particles, most focusing on fine grinding ( $<3 \mathrm{~mm}$ ) (Arcari, Martins, Tomazi, \& Santos, 2016; B. de C. Silva, 2018). Our hypothesis was that silage with smaller particle sizes and longer storage times would alter the chemical composition and increase the aerobic stability of the material. Therefore, the objective of the current study was to measure the grinding granulometry associated with the storage time of rehydrated corn silage, as well as the chemical composition, fermentative characteristics, and aerobic stability, so as to identify strategies to improve the feed efficiency of ruminants.

\section{Materials and Methods}

\section{Sample preparation}

The experiment was carried out at the Laboratory of Bromatology, Department of Animal Science, Unoesc Campus Xanxerê, Santa Catarina, Brazil. The corn used in the experiment was purchased from local stores. Five granulometries were used, with grinding in 2-, 4-, 6-, 8-, and 10-mm sieves, subjected to three storage times: 14,28 , and 56 days, arranged in a completely randomized design in a $5 \times 3$ factorial arrangement. Each treatment had six repetitions, totaling 90 experimental units (EU). The ground corn was rehydrated using distilled water, to reach $65 \%$ dry matter (DM).

The samples were ensiled using PVC mini-silos, containing a Bunsen-type valve for gas escape, measuring $10 \mathrm{~cm}$ in diameter and $25 \mathrm{~cm}$ height, total volume 1,963 L. Approximately $2.5 \mathrm{~kg}$ of the rehydrated corn mass was used in each mini-silo, aiming at specific mass of approximately $880 \mathrm{~kg}$ of DM $\mathrm{m}^{-3}$, equivalent to $1100 \mathrm{~kg}$ of natural material $\mathrm{m}^{-3}$, similar a previously described process (Arcari et al., 2016).

\section{Fermentation profile and aerobic stability}

Measurements of fermentative losses by gases and effluents were carried out according to Jobim, Nussio, Reis and Schmidt (2007). Some of the silo material, after being removed (approximately $1 \mathrm{~kg}$ ), underwent 
aerobic stability assessments, according to a previously described method (Tres, Jobim, Rossi, Silva, \& Poppi, 2014). The mass temperature was recorded using dataloggers inserted in the removed material at 30-minute intervals over four days. The material exposed to the air was weighed to determine dry matter losses (Jobim et al., 2007) and the $\mathrm{pH}$ of the mass was measured daily at 16:00. At each opening time of the mini-silos, approximately $10 \mathrm{~g}$ of sample were collected, $90 \mathrm{ml}$ of distilled water were added, and the $\mathrm{pH}$ was read after a minute with using a digital probe (Hanna, model HI 8424).

Ambient temperature during aerobic stability of the first opening was measured at 9:00 am, 3:00 pm and 9:00 pm, using a digital skewer thermometer (Incoterm $\left.{ }^{\circledR}\right)$. At the second and third opening, the measurements were performed using a datalogger placed on the bench, between the buckets containing the silages exposed to aerobiosis, with readings every 30 minutes.

Breaking aerobic stability was considered when the samples achieved 2 ${ }^{\circ} \mathrm{C}$ above room temperature (Kung, Schmidt, Ebling, \& Hu, 2007). The peak temperature of each treatment was calculated as the average of the highest temperature point obtained by the datalogger of each repetition within the same treatment, over the period of aerobic exposure.

\section{Chemical composition}

The rest of the removed material was dried in a forced ventilation oven at $55^{\circ} \mathrm{C}$ for 72 hours, ground using a Willey mill with a 1-mm sieve, and the variables DM (dry matter), mineral matter (MM), crude protein (CP), and ether extract (EE) were calculated according to the Association of Official Analytical Chemists [AOAC] (1991). Neutral detergent fiber (NDF) and acid detergent fiber (ADF) components were analyzed as previously described (Van Soest, Robertson, \& Lewis, 1991). Soluble protein was determined according to the methodology described by Licitra, Hernandez and Soest (1996).

\section{Microbiology}

Fifty grams of silage were collected from each sampling unit and were packaged on ice to preserve the characteristics of the silage. Samples were sent to the Microbiology Laboratory of the Food Engineering course at the University of the State of Santa Catarina, Campus Pinhalzinho, SC, to count lactic acid bacteria ( $L A B)$, molds, and yeasts. Using a sterile spatula, $10 \pm 0.2 \mathrm{~g}$ of silage were weighed, 90 $\mathrm{ml}$ of peptone water (dilution 10-1) was added, and the material was homogenized in a digester for 60 seconds. Five additional dilutions, up to $10^{-6}$, were prepared by transferring $1 \mathrm{ml}$ of the $10^{-1}$ dilution in $9 \mathrm{ml}$ of peptone water, obtaining $10^{-2}$, and so on. For the LAB counts, $100 \mu \mathrm{L}$ of the appropriate dilution $\left(10^{-6}\right)$ of the sample was inoculated on Man, Rogosa and Sharpe agar and incubated aerobically at $36{ }^{\circ} \mathrm{C}$ for 48 h (Hwanhlem, Ivanova, Haertlé, Jaffrès, \& Dousset, 2017). To count molds and yeasts, 100 $\mu \mathrm{L}$ of the appropriate dilutions of the sample were inoculated in potato dextrose agar, and incubated at $25^{\circ} \mathrm{C}$ for 5 days (Instrução Normativa $\left.n^{\circ} 62,2003\right)$. The counting results were expressed as log CFU g ${ }^{-1}$. 


\section{In vitro digestibility of $D M$}

The in vitro digestibility of DM was evaluated using the methodology described by Holden (1999). The ruminal inoculum were collected from freshly slaughtered cattle at a slaughterhouse in the municipality of Xanxerê, $\mathrm{SC}$, and were transported in a thermal box to the laboratory at $39{ }^{\circ} \mathrm{C}$ to maintain their microbiological activity.

The previously ground food was weighed in quadruplicate, including $0.5 \mathrm{~g}$ of partially dried sample in heat-sealed nylon bags with a porosity of 57 microns. Buffer solution (solutions $A+B$ ) was prepared in preheated containers $\left(39^{\circ} \mathrm{C}\right)$, reaching a final $\mathrm{pH}$ of 6.8 and a temperature of $39{ }^{\circ} \mathrm{C}$. Then, the filters were placed in the rumen fermenter jars containing inoculum (400 mL), $1600 \mathrm{~mL}$ of buffer solution, and 25 nylon bags with sample, then placed in an incubator (TECNAL, Piracicaba, SP) and incubated for 48 hours at $39{ }^{\circ} \mathrm{C}$. Then, the jars were drained and the nylon bags were washed in the jug itself five to six times with distilled water, and the gas contained in them was removed using hand pressure. The material was placed in an oven at $105^{\circ} \mathrm{C}$ for 24 hours for drying. The nylon bags were weighed with the residues to determine the dry matter (DM) and the in vitro digestibility coefficient of DM, calculated as the difference between the incubated food and the residue after incubation.

\section{Data analysis}

The data were analyzed with respect to the presence of outliers, normality of residues (Shapiro-Wilk test) and homogeneity of variances (Hartley test). Response losses during aerobic stability and hours to reach the peak temperature were transformed into inverses and logs, respectively. The treatments were distributed in a completely randomized design in a factorial arrangement 5 (grain sizes) $\times 3$ (storage times) using Proc Mixed (SAS University Edition) with fixed effects of granulometry, storage time, and interaction between factors. The averages were obtained using the least squares method. The variables $\mathrm{DM}, \mathrm{MM}, \mathrm{CP}, \mathrm{NDF}, \mathrm{ADF}, \mathrm{pH}$, molds and yeasts, fermentative losses, in vitro digestibility, and aerobic stability were subjected to analysis of variance and the Tukey test used to compare means, considering a significance of $5 \%$. Polynomial contrasts were used to evaluate the effect of storage time.

Lactic acid bacteria counts were not normally distributed according to Wilcoxon's non-parametric analysis. Regarding normality of the residues, we used the Kruskal-Wallis test at $5 \%$ significance. The counting of molds and yeasts was only considered for periods of 14 and 28 days of storage. The 56-day time data were disregarded due to inconsistency.

\section{Results and Discussion}

\section{Chemical composition}

There was a significant interaction of treatment and opening time for the recovery of DM from rehydrated corn $(P<0.05$, Figure 1a). The storage time interfered only in the 2-mm and 8-mm treatments. All treatments showed an increase in DM recovery from 14 to 28 days, except for the $6-\mathrm{mm}$ treatment, which showed a decrease. From 28 to 56 days, the 8-mm treatment showed a decrease, while the other treatments showed increases in the 
percentage of DM. There was a significant interaction between treatment and time for $C P$ ( $P<0.001$, Figure 1b). All treatments showed a reduction in CP content from 14 to 28 days of silage, with the exception of 2-mm, which showed a small increase. From 28 to 56 days, treatments 2-mm and $10-\mathrm{mm}$ showed reductions in the percentage of $\mathrm{CP}$, while the others increased.

There was a significant interaction between treatment and storage time for NDF, decreasing over time $(p=0.04$, Figure 1c). All treatments showed a decrease in the percentage of NDF from 14 to 28 days, and similarly, from 28 to 56 days, except for the 10-mm treatment, which increased during the final storage period. The EE showed a significant interaction between treatments and storage times ( $p<0.005$, Figure $1 d$ ). The $6-\mathrm{mm}$ treatment showed a significant decrease from 14 to 28 days of fermentation, with a subsequent increase in the percentage of $E E$ from 28 to 56 days. The other treatments did not show significant changes over the chosen periods.

The silage process is designed to store a food for long periods and to promote greater nutritional availability using the physical action of reducing the food particles for microbial fermentation, as well as by the chemical action of the combination of high temperature and humidity in the fermentation environment; that is, the combination of physical and chemical processing improves the efficiency of digestion of grains processed by ruminants (Reis, Moura, \& Malacco, 2014). The percentages of NDF and ADF became lower as the fermentation time increased. This process can be explained in part by the oxidation of the particles at the time of ensiling, by hydrolysis of some of the NDF component, especially hemicellulose, or by the formation of effluents during fermentation, where the soluble compounds are proportionally increased with respect to the fibrous fraction of the silage by the formation of fermentation acids (Neumann et al., 2007). In a meta-analysis of more than 6,000 wet grain corn silage samples, Ferraretto, Taysom, Shaver, \& Hoffman (2014) found mean values of $7.1 \%$ for NDF and $2.6 \%$ for ADF, that is, results inferior to those obtained in the present study.

There was a significant effect of storage time (for the fraction of soluble protein ( $p<0.001$, Figure 2a). The soluble protein of the silages significantly increased linearly with the storage time $(P<0.001)$. There were no significant interactions between treatments and storage times for ADF ( $p=0.09$ ); however, a significant reduction was observed according to the storage time ( $p<0.001$, Figure $2 b$ ). We found increased soluble protein content over the course of fermentation time. Working with fine-grind RCG, B. de C. Silva (2018) observed a reduction in the levels of soluble protein as the storage time increased. Rehydration and ensilage, through the fermentation process of the material inside the silo, reduce the concentration of prolamines due to proteolytic activity, increasing the soluble protein content over time (Kung, Windle, \& Walker, 2014). Similarly, Saylor et al. (2019) observed that high-moisture corn silage with fine grinding showed higher concentrations of soluble protein than produced by coarse grinding, as well as a positive effect of the storage time for this same component, another positive effect of which was increased in situ degradability of starch from these silages. 


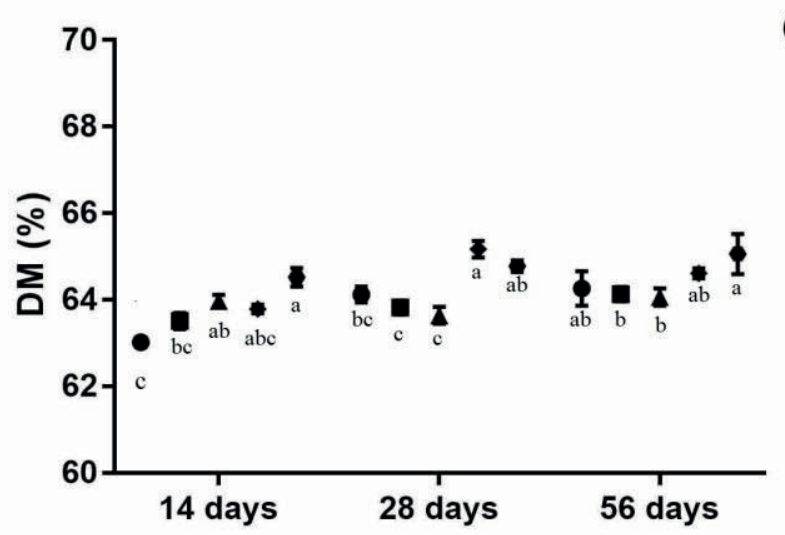

(a)

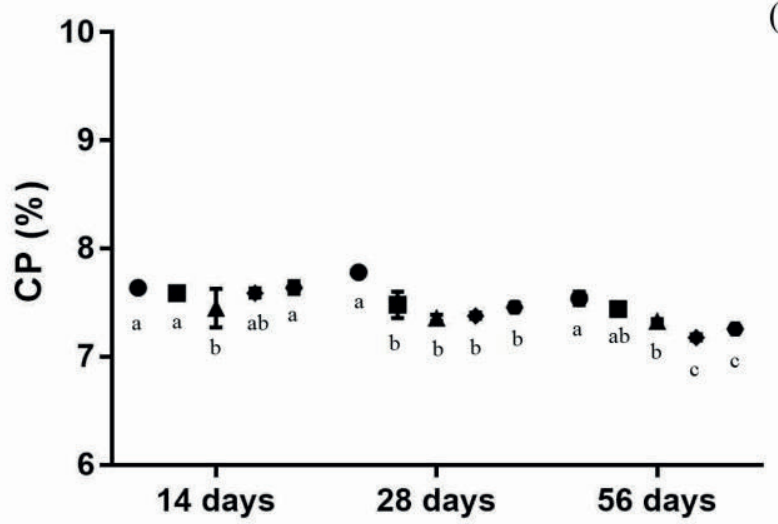

(b)

(c)
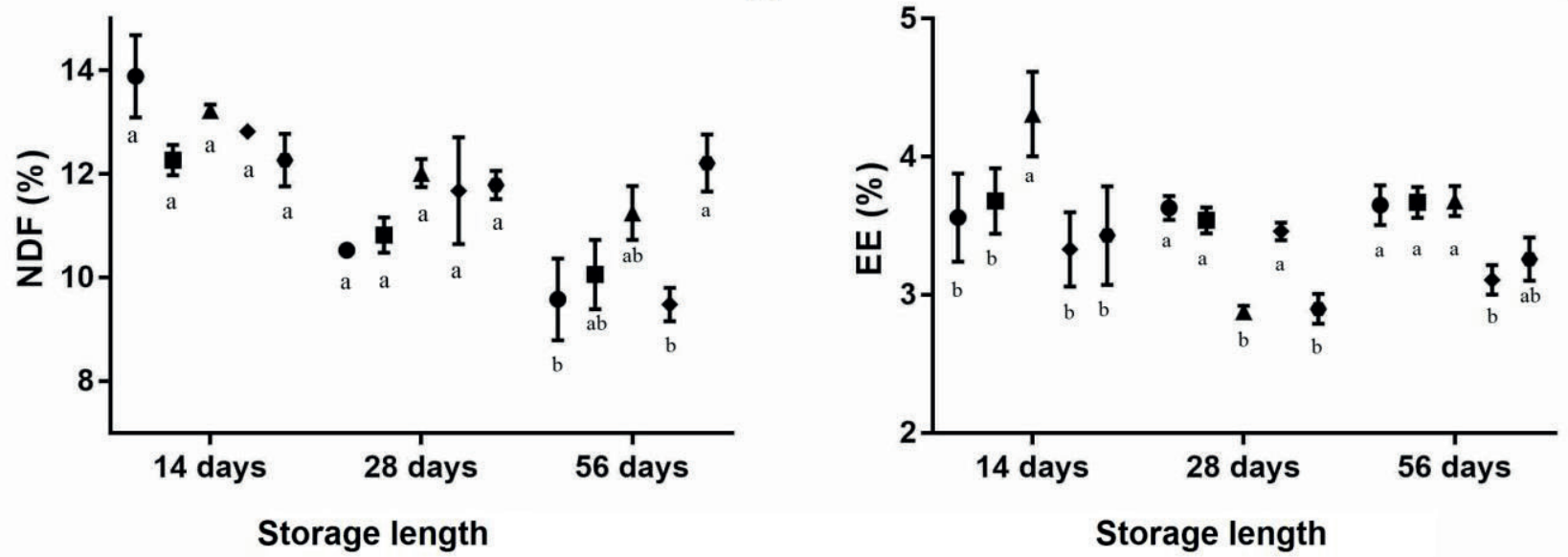

- $2 \mathrm{~mm}$

\section{Storage length}

Figure 1. Effect of corn milling granulometry and storage time on dry matter (a), crude protein (b), neutral detergent fiber (c) and ether extract (d) of rehydrated corn silage under five granulometries milling, submitted to three fermentation times (14, 28, and 56 days). Averages within the same day with different letters differ $(a-e)$ differ $(P<0.05)$. For panel $A$, effects of treatment $(P<0.001)$, time $(P$ $<0.001)$ and their interaction $(P<0.001)$; SEM $=0.08$. For panel $B$, effects of treatment $(P<0.001)$, time $(P<0.001)$ and their interaction $(P<0.001)$; SEM $=0.04$. For panel $C$, effects of treatment $(P>$ $0.06)$, time $(P<0.001)$ and their interaction $(P<0.04)$; $S E M=0.25$. For panel $D$, effects of treatment $(P<0.01)$, time $(P<0.01)$ and their interaction $(P<0.01)$; SEM $=0.06$. Error bars indicate SEM. 


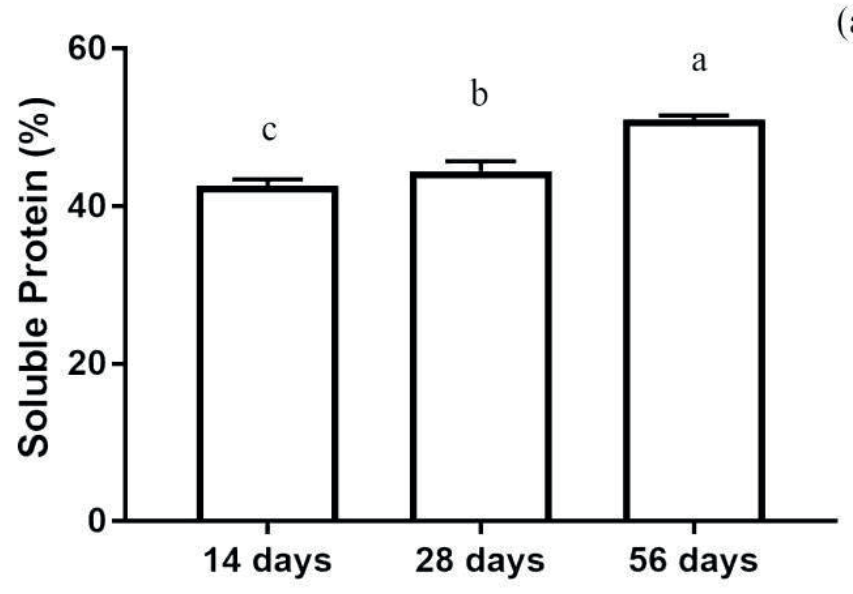

(a)

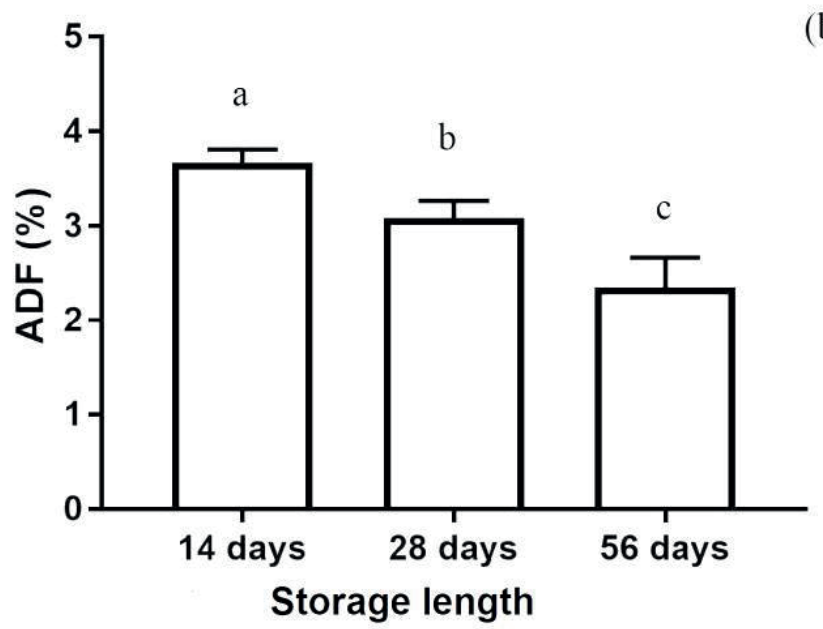

Figure 2. Effect of storage time on soluble protein (a) and acid detergent fiber (b), from rehydrated corn silage under five milling sizes $(2,4,6,8$ and $10 \mathrm{~mm})$, submitted to three times fermentation $(14,28$, and 56 days). For panel $A$, effects of treatment $(P<0.51)$, time $(P<0.001)$ and their interaction $(P<0.65)$; SEM $=0.84$. For panel $B$, effects of treatment $(P<0.34)$, time $(P<0.001)$ and their interaction $(P<0.09) ; S E M=0.21$. Error bars indicate SEM.

The specific mass $\left(\mathrm{Kg} \mathrm{m}^{-3}\right)$ showed a significant interaction between treatment and time at the moment of opening the silos ( $p$ $<0.025$, Figure 3a). With the exception of the 10-mm treatment, which showed a decrease, the other treatments showed increases in specific mass, from 14 to 28 days. From 28 to 56 days, all treatments showed decreases.

The specific mass achieved was higher for treatments with less granulometry, due to the fact that there was better conditioning of the smaller particles than of the larger particles inside the silo. According to Pereira (2012), compacted silages with lower specific masses tend to have greater residual air in the ensiled material, with longer breathing periods, resulting in greater consumption of soluble carbohydrate, reduction in the production speed of organic acids, and greater final $\mathrm{pH}$ of the silage. Wilkinson and Davies (2013) stated 
that silages of higher densities and higher concentrations of DM have less permeability than silages of lower densities and lower DM, thereby affecting aerobic stability through the entry of air through the face of the silo panel. This can be seen in our results, where the treatments showed similar behaviors between the DM and specific mass variables, as well as in the DM losses during aerobic stability, with an increase from 14 to 28 days, and later decrease for 56 days, in general, for the treatments evaluated.
The $\mathrm{pH}$ of the samples at the time of opening of the silos showed a decrease from the first to the second period, and an increase in the last evaluated period; however, all showed values below 4, demonstrating that there was fermentation efficiency, with a rapid decrease in the $\mathrm{pH}$ of the silages, even with short fermentation period (14 days). Similarly, Mendes (2013) obtained values of 4.06, 3.91, and 3.95 for rehydrated corn silage ground at $2 \mathrm{~mm}$ and fermented for 14,28 , and 56 days, respectively.

है

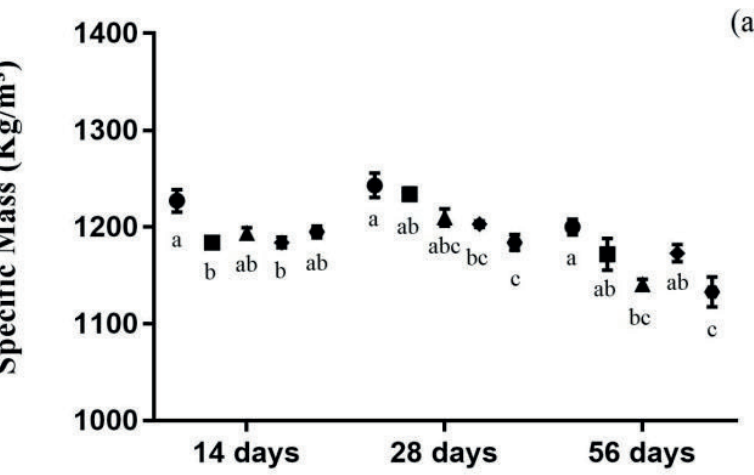

(a)

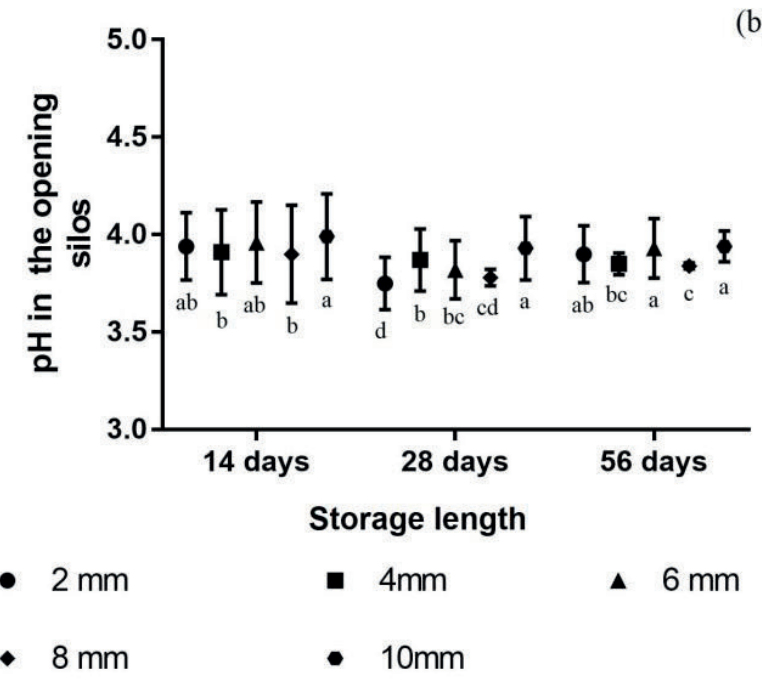

Figure 3. Effect of storage time on specific mass (a) and $\mathrm{pH}$ on the opening of rehydrated corn silage silos (b) under five grinding granulometries, submitted to three fermentation times $(14,28$, and 56 days ). Averages within the same day with different letters differ (a-e) differ $(P<0.05)$. For panel $A$, effects of treatment $(P<0.001)$, time $(P<0.001)$ and their interaction $(P<0.0025)$; SEM $=$ 3.82. For panel $B$, effects of treatment $(P<0.001)$, time $(P<0.001)$ and their interaction $(P<0.001)$; $\mathrm{SEM}=0.008$. Error bars indicate SEM. 
The variables mineral matter (MM) and in vitro digestibility in dry matter (DMIVD) did not show significant effects for the treatments (Table 1). In a meta-analysis, Ferraretto, Crump and Shaver (2013) observed an effect of the average particle size of rehydrated corn silage on dry matter digestibility, with values of $71.9 \%$ and $69.4 \%$ for smaller particles and those larger than $2 \mathrm{~mm}$, respectively. Likewise, the digestibility of starch in the total tract also decreased with larger particles (89.5\%) compared to smaller ones (95.2\%). The increase in the rate of passage of thicker and denser particles through the gastrointestinal tract may explain the effect of particle size on the digestibility of starch in the total tract (Firkins, Eastridge, St-Pierre, \& Noftsger, 2001).
The digestibility of ruminal starch is higher in cows fed coarse ground corn diets. Contradictory ruminal parameters and ruminal starch digestibility data may suggest a faster rate of digestion and flow to fine ground corn (Fredin, Ferraretto, Akins, Bertics, \& Shaver, 2015). The increase in the digestibility rate of ruminal starch from fine ground corn may be the result of an increase in the surface area for bacterial fixation and enzymatic digestion (Ferraretto et al., 2013; Fredin et al., 2015). The in vitro digestibility of silages did not show significant differences between treatments and storage times, possibly due to the fact that there was uniform grinding of the pre-dry matter of all treatments. Thus, all treatments were subjected to similar conditions of particle size upon exposure to microbial degradation in the artificial rumen.

\section{Table 1}

Mineral matter (\%), in vitro dry matter degradability (\%) and peak temperature ( $\left.{ }^{\circ} \mathrm{C}\right)$ of rehydrated corn silages during aerobic exposure

\begin{tabular}{|lcccccccc}
\hline & \multicolumn{7}{c|}{ Granulometry $(\mathrm{mm})$} \\
\hline Variable & 2 & 4 & 6 & 8 & 10 & SEM & $\mathrm{L}$ & $\mathrm{Q}$ \\
\hline MM (\%) & 1.25 & 1.19 & 1.27 & 1.24 & 1.69 & 0.212 & 0.17 & 0.25 \\
\hline DMIVD (\%) & 94.25 & 94.83 & 94.61 & 95.27 & 94.78 & 0.329 & 0.15 & 0.31 \\
\hline Peak T $\left({ }^{\circ} \mathrm{C}\right)$ & $38.06 \mathrm{a}$ & $30.14 \mathrm{~b}$ & $29.86 \mathrm{~b}$ & $27.65 \mathrm{~b}$ & $31.09 \mathrm{~b}$ & 0.705 & $<0.001$ & $<0.001$
\end{tabular}

MM: mineral matter. DMIVD: in vitro digestibility of dry matter. SEM: Standard error of the mean. Means with lowercase letters on the line indicate differences between treatments ( $p<0.05)$. Effects: (L) - Linear, (Q) - Quadratic.

Fermentation profile and aerobic stability

The $\mathrm{pH}$ at the opening of the silos showed a significant interaction between treatments and storage times $(p<0.001$, Figure 3b). From 14 to 28 days, all treatments showed $\mathrm{pH}$ reductions. From 28 to 56 days, the $4-\mathrm{mm}$ treatment showed a new reduction, while the other treatments gave rise to higher $\mathrm{pHs}$.
The $\mathrm{pH}$ during aerobic stability showed a triple interaction between treatments, storage times, and days after opening ( $p$ $<0.001$, Figure 4). From the opening day (day 0) to day 1, all treatments maintained constant $\mathrm{pH}$. From day 1 to day 2 , the treatments from $14 \mathrm{~d}$ showed a sudden increase in comparison to the other treatments from time 28 and 56 days, except 8-mm (14 d), which increased 
with less magnitude; the treatments of 28 days showed slight elevations, while 8-mm (28 d) maintained a small increase until the third day; treatments 4 and $8 \mathrm{~mm}$ of time 56 days showed a slight reduction in $\mathrm{pH}$ in this period, while the others remained practically constant. From day 2 to day 3 , the treatments maintained increased in $\mathrm{pH}$, particularly 8-mm (14 d), which showed a more pronounced increase, reaching the highest $\mathrm{pH}$ value obtained (7.08); with the exception of 8-mm (28 d), which followed a slight fall, registering the lowest $\mathrm{pH}$ value obtained (3.68). the other treatments (28 d) continued to increase; 4-mm (56 d) and 8-mm treatments (56 d) decreased slightly, while the others (56 d) continued to increase. From day 3 to day 4, 10 (14 d) still showed an increase, while the other treatments showed lower values; treatment 8-mm (28 d) showed a small reduction, while the remaining $28 \mathrm{~d}$ continued to increase, especially 10-mm (28 d); 6-mm (56 d) and 10-mm (56 d) showed higher elevations while the others showed slight increases in $\mathrm{pH}$. From day 4 to day 5 (final), all treatments A decreased their $\mathrm{pH}$; 4-mm (28 d) and 8-mm (28 d) treatments showed increases, while 2-mm (28 d), 6-mm (28 d), and 10-mm (28 d) suffered reductions; 2-mm (56 d) and 4-mm (56 d) treatments showed small increases, while $6-\mathrm{mm}$ (56 d) and 10-mm (56 d) reduced, and 8-mm (56 d) remained practically constant throughout the period of aerobic exposure, presenting the lowest $\mathrm{pH}$ (3.88) on the final day evaluated.

There was a significant interaction between treatments and storage times ( $p$ $<0.001$ ) when the break in aerobic stability was evaluated (Figure 5a). From 14 to 28 days, all treatments showed an increase in the number of hours to achieve a break in aerobic stability; however, the 8-mm (28 d) treatment reached the evaluation time limit ( 87.5 hours) without showing a difference greater than $2{ }^{\circ} \mathrm{C}$ in relation to room temperature, that is, there was no break in aerobic stability for this treatment with 28 days of storage. From 28 to 56 days, treatments 2-, 6-, and 10-mm (56 d) showed a slight increase in the number of hours spent to break stability; treatment 4-mm (56 d) reached 75.5 hours for the break, while treatment 8-mm (56 d) did not show stability break, in the same way as at 28 days. 

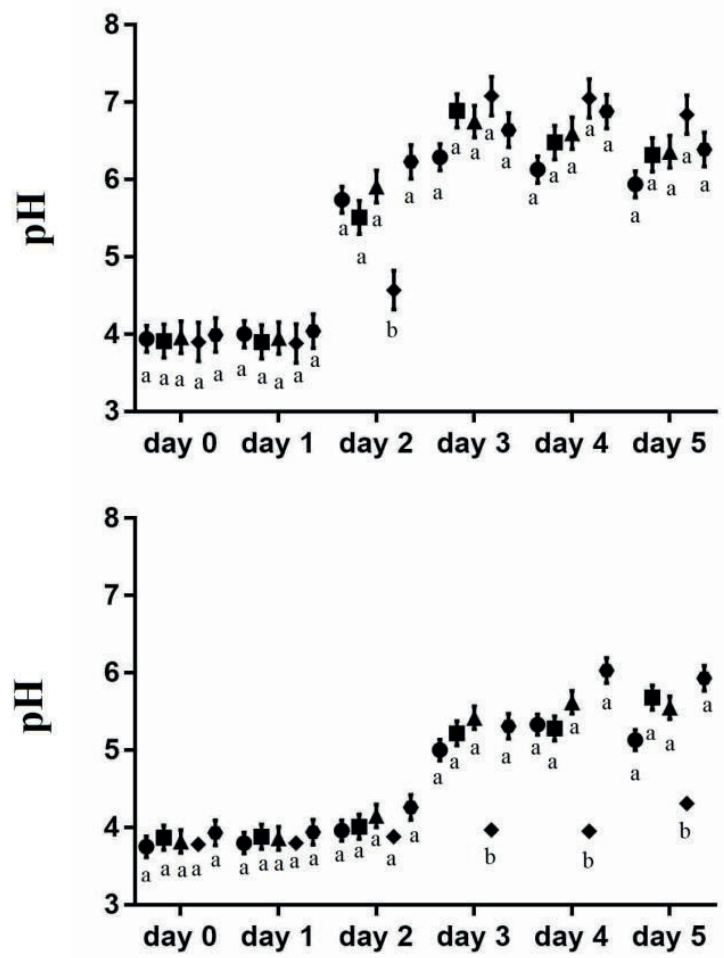

(b)

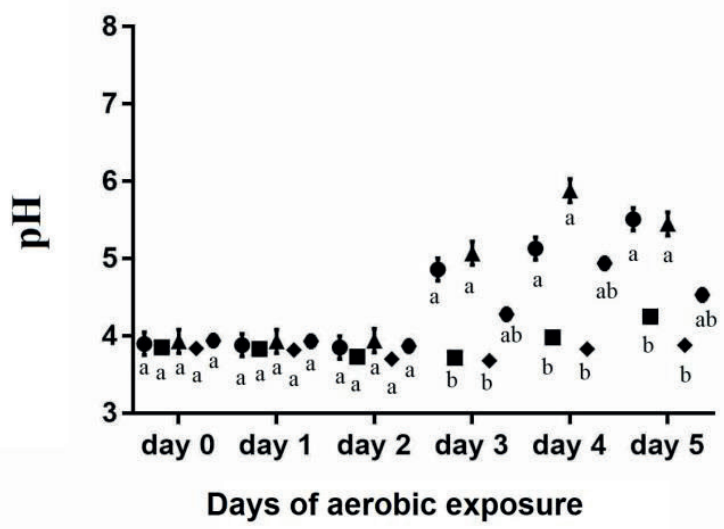

(c)

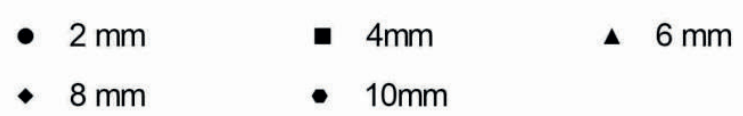

Figure 4. Effect of corn milling granulometry and storage time on the $\mathrm{pH}$ of rehydrated corn silages under five milling granulometries, subjected to three fermentation times: 14 days (a), 28 days (b) and 56 days (c), assessed over five days of aerobic exposure. Averages within the same day with different letters differ $(a-e)$ differ $(P<0.05)$. For panel $A$, effects of treatment $(P<0.001)$, time $(P<$ $0.001)$ and their interaction $(P<0.001)$; SEM $=0.007$. For panel $B$, effects of treatment $(P<0.001)$, time $(P<0.001)$ and their interaction $(P<0.001)$; SEM $=0.013$. For panel $C$, effects of treatment $(P$ $>0.001)$, time $(P<0.001)$ and their interaction $(P<0.001)$; SEM $=0.053$. Error bars indicate SEM. 
There was a significant interaction between treatments and storage time when DM losses were measured over the aerobic stability assessment period (Figure 5b, $\mathrm{P}<0.001$ ). From 14 to 28 days of silage, treatment $8-\mathrm{mm}$ (28 d) showed a decrease in the percentage of losses, 2-mm (28 d) showed a slight increase, while the others showed abrupt increases in losses. From 28 to 56 days, treatment $8-\mathrm{mm}$ (56 d) increased slightly, treatment 2-mm (56 d) continued to increase and the others showed a decrease in the percentage of losses in aerobiosis.

There was also a significant interaction between treatments and storage times in the number of hours required to reach the peak temperature of the aerobic silages (Figure $5 \mathrm{c}$, $P<0.001$ ). From 14 to 28 days, treatments of smaller particle size (2-, 4- and 6-mm) showed increases in the time required to reach the peak temperature, while treatments with larger particles (8-and 10- $\mathrm{mm}$ ) registered the peak of temperature at the end of the evaluation time (87.5 hours). From 28 to 56 days, treatments 2and 4-mm required longer periods to reach the peak temperature; treatment 6-mm took only 2 hours longer than the time 28 days to reach the peak, and treatments $8-\mathrm{mm}$ (56 d) and 10-mm (56 d) showed significant reductions in the time needed to reach the highest temperature over the evaluated period. The peak temperature reached by the silages during the period of aerobic exposure showed a quadratic effect for the treatments evaluated, decreasing as the particle size progressed until the $8-\mathrm{mm}$ treatment, and increasing from the peak temperature for the $10-\mathrm{mm}$ treatment. The increase in storage time had a decreasing effect on the peak temperature of the silages during aerobic exposure (Figure $5 d$ ).

Silages that fermented for 14 days remained less stable than those of 28 and 56 days, with a linear effect of fermentation time to break aerobic stability. These results suggest that longer fermentation time for rehydrated corn silage gives rise to longer periods of maintaining physical-chemical qualities, with fewer chances of attack by microorganisms that would degrade the organic matter. Silages stored for longer periods are more stable when exposed to air, probably due to the reduction of the yeast population present in the silage (Junges, 2014). This factor is directly related to the time necessary for the silage in aerobic exposure to reach high temperatures as a result of the microbial attack.

Silages with smaller particle sizes took longer to reach the peak temperature in aerobic conditions as they fermented for longer periods of time. The larger particles (8and $10-\mathrm{mm}$ ) showed a different effect, in which the peak temperature occurred at the end of the evaluation period ( 87.5 hours) for the time of 28 days, but decreased at the period of 56 days. Evaluating fermented silages for 45 days, C. M. Silva et al. (2016) observed that RCG took about 18 hours to reach $2{ }^{\circ} \mathrm{C}$ above room temperature, while HMC took 43 and 74 hours to show the same behavior. 


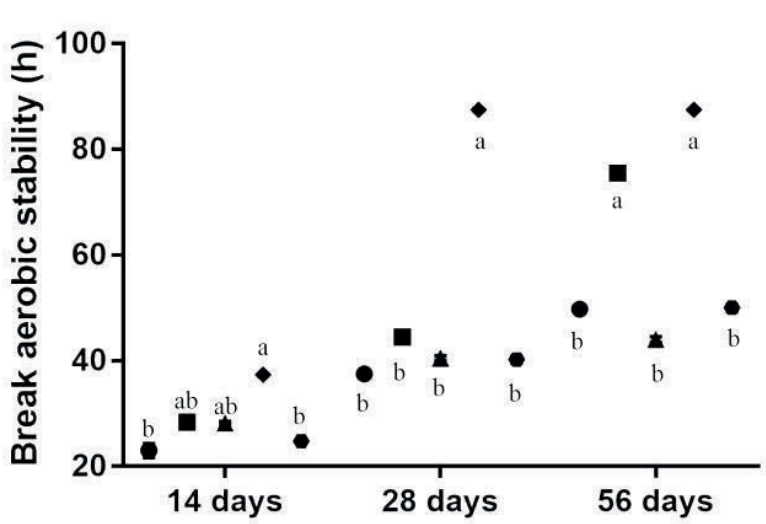

(a)

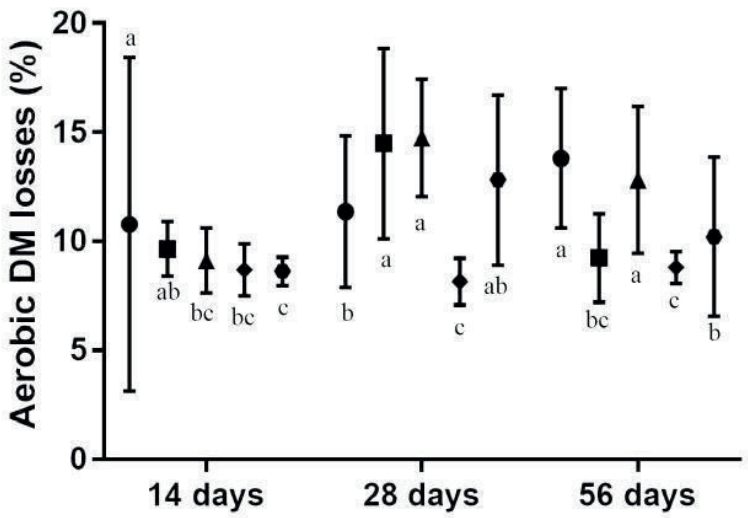

(b)

(c)

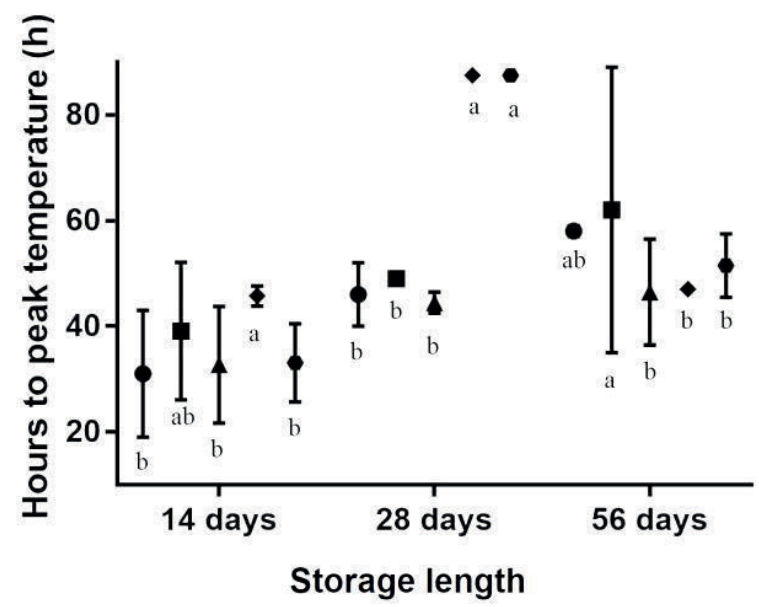

- $2 \mathrm{~mm}$

- $4 \mathrm{~mm}$

\ $6 \mathrm{~mm}$

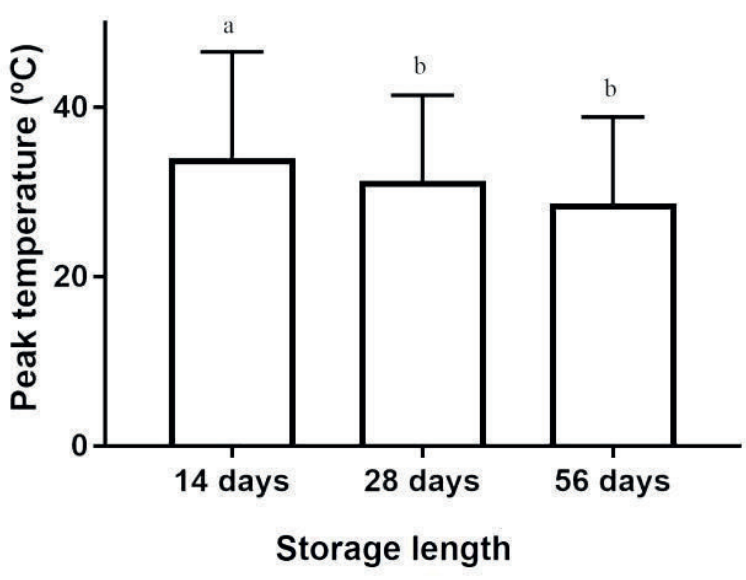

(d)

Figure 5. Effect of corn milling granulometry and storage time on breaking aerobic stability (a), losses during aerobic stability ${ }^{1}$ (b), hours to reach peak temperature ${ }^{2}$ (c), and effect of storage for peak temperature (d) of rehydrated corn silage under five milling sizes, subjected to three fermentation times $(14,28$, and 56 days). Averages within the same day with different letters differ (a-e) differ $(P<0.05)$. ${ }^{1}$ The data of losses during aerobic stability were transformed into inverse. ${ }^{2}$ The data for hours to reach the peak temperature were logged. For panel $A$, effects of treatment $(P<0.001)$, time $(P<0.001)$ and their interaction $(P<0.001)$; SEM $=0.267$. For panel $B$, effects of treatment $(P<0.001)$, time $(P<0.001)$ and their interaction $(P<0.001)$; $S E M=3.14$. For panel $C$, effects of treatment $(P>0.001)$, time $(P<0.001)$ and their interaction $(P<0.001)$; $S E M=2.79$. For panel $D$, effects of treatment $(P<0.01)$, time $(P<0.01)$ and their interaction $(P<0.12) ; S E M=0.679$. Error bars indicate SEM.

The losses due to effluents during the fermentation process showed significant interaction between treatments and storage times (Figure 6a, $\mathrm{P}<0.001$ ). From 14 to 28 days, all treatments showed insignificant increases in the percentage of losses. From 28 to 56 days, losses continued to increase for all treatments, particularly 4-mm (56 d) and 6-mm (56 d), in which the percentage of losses was four-fold greater compared to that of 28 days. There was also a significant treatment $x$ time interaction for losses by gases in fermentation (Figure 6b, 
$\mathrm{P}<0.001)$. All treatments showed a reduction in losses from 14 to 28 days, especially $10-\mathrm{mm}$ (28 d), which reduced the percentages of gases by three-fold; the highest observed value was $0.69 \%$ at 14 days of storage. From 28 to 56 days, treatments 4-mm (56 d) and 6-mm (56 d) followed with decreased losses, 2-mm (56 d) remained constant compared to 28 days, 8-mm (56 d) showed increased losses, and 10$\mathrm{mm}$ (56 d) increased the loss percentage by almost three-fold compared to that of $10-\mathrm{mm}$ $(28 \mathrm{~d})$.
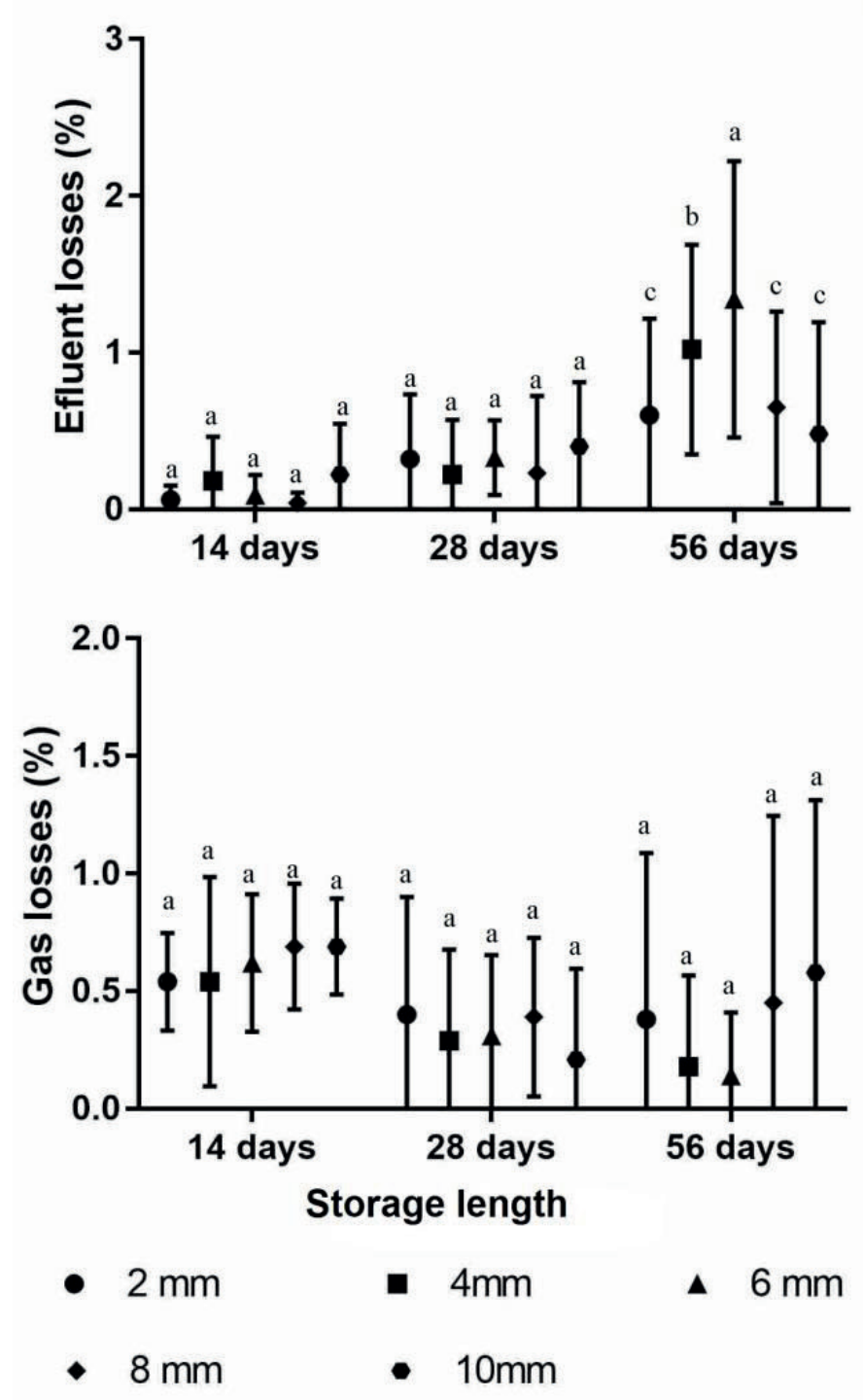

(b)

Figure 6. Effect of corn milling granulometry and storage time on effluent losses (a) and gas losses (b) of rehydrated corn silage under five milling sizes, subjected to three fermentation times $(14,28$, and 56 days). Averages within the same day with different letters differ (a-e) differ $(P<0.05)$. For panel $A$, effects of treatment $(P<0.002)$, time $(P<0.001)$ and their interaction $(P<0.001)$; SEM $=$ 0.047. For panel $B$, effects of treatment $(P<0.02)$, time $(P<0.001)$ and their interaction $(P<0.02)$; $\mathrm{SEM}=0.025$. Error bars indicate SEM. 


\section{Microbiology}

Lactic acid bacteria counts did not show normal data distribution according to Wilcoxon's non-parametric analysis, comparing only the treatments within each fermentation time, making it impossible to make comparisons between storage times (Table 2). Within 14 days of ensiling, there was a significant effect for treatments, in which the 8-mm was significantly smaller than the others ( $p<0.01$ ). At 28 days, the treatments showed statistically equal counts, with a tendency to significance. At 56 days, the $8-\mathrm{mm}$ treatment was significantly less than that of the other treatments $(p<0.01)$.

There was a significant effect of treatments for 14 days ( $p<0.01$ ), in which the 4-mm treatment was significantly greater than the others; the 2-mm treatment did not differ from the 4- and 6-mm treatments; however they were greater than the $8-\mathrm{mm}$ and $10-\mathrm{mm}$ treatments. The 6-mm treatment was less than the 4-mm treatment, which did not differ from the 2-, 8-, and $10-\mathrm{mm}$ treatments. The storage time of 28 days showed no significant differences between treatments. There was a significant effect of storage time only for the 2 - and 4-mm treatments ( $p<0.001$ ), which showed higher values at 14 days, and lower at 28 days of ensiling.

Our results indicate that there is a significant relationship between $L A B$ and other parameters, such as mold, $\mathrm{pH}$ in aerobic conditions and the break in aerobic stability. As the storage time was increased, the LAB and mold counts decreased the mold count decrease was likely due to increased acetic acid concentrations (Carvalho, 2014). This was reflected in better quality of the conserved silage, due to the lower susceptibility to microbial attack, and therefore longer intervals to raise the temperature and break aerobic stability. Silages fermented for longer periods also showed significant decreases in the maximum temperature reached, with a direct relationship between $\mathrm{pH}$ and aerobic stability. According to Bernardes and Chizzotti (2012) silages without inoculation, such as the one used in our work, are probably not capable of producing sufficient short-chain fatty acids to inhibit yeasts and molds. However, even though we did not measure short-chain fatty acids, we observed that there were signs of mold inhibition as the storage time increased. Acetic acid, which has antifungal characteristics, retards the microbial degradation of the silage exposed to the air. 
Table 2

Counting of Acid-Lactic and Mold Bacteria * (log CFU g-1) in rehydrated corn silage from Non-Parametric Analysis

\begin{tabular}{lccccccc}
\multicolumn{7}{c}{ Granulometry $(\mathrm{mm})$} \\
Variable & 2 & 4 & 6 & 8 & 10 & SEM & P-value \\
LAB 14 d & $7.89 \mathrm{a}$ & $8.14 \mathrm{a}$ & $7.9 \mathrm{a}$ & $7.39 \mathrm{~b}$ & $7.58 \mathrm{a}$ & 0.0704 & $<0.01$ \\
LAB 28 d & 6.61 & 7.22 & 7.09 & 6.13 & 6.93 & 0.1519 & 0.05 \\
LAB 56 d & $4.88 \mathrm{a}$ & $4.52 \mathrm{a}$ & $5.13 \mathrm{a}$ & $4.27 \mathrm{~b}$ & $4.79 \mathrm{a}$ & 0.08 & $<0.01$ \\
Molds 14 d & $4.98 \mathrm{abA}$ & $5.38 \mathrm{aA}$ & $3.9 \mathrm{bc}$ & $3.14 \mathrm{c}$ & $3.04 \mathrm{c}$ & 0.2297 & $<0.01$ \\
Molds 28 d & $3.27 \mathrm{~B}$ & $2.98 \mathrm{~B}$ & 3.2 & 2.7 & 2.61 & 0.1182 & 0.91
\end{tabular}

LAB, Lactic Acid Bacteria; SEM, Average Standard Error. Means accompanied by lowercase letters on the lines differ between treatments $(p<0.05)$. Averages accompanied by capital letters in the columns differ between storage times ( $p$ $<0.05)$. $\left(^{*}\right)$ The 56-day mold and yeast count was discarded due to inconsistency in the data obtained.

In general, particle size was not a major factor for promoting changes in the evaluated characteristics; however, the exposure of silages to various storage periods demonstrated more significant effects on the characteristics of composition, fermentation profile, microbiological count, and factors related to the aerobic stability of rehydrated corn silages. New studies are needed to seek information that will help to better elucidate the processes resulting from the fermentation of rehydrated corn grain silages with the granulometry used in this study, including the use of additives, such as homoor heterofermentative inoculants, as well as enzymes such amylases and proteases.

\section{Conclusion}

Rehydrated corn silages with smaller particles (2- and 4-mm) showed higher LAB and mold counts, higher levels of $\mathrm{CP}$ and $\mathrm{EE}$, and higher density in the compaction process than those of coarser particles. However, they showed lower percentages of DM and were susceptible to microbial attack and temperature rise more quickly than were coarse particles during the storage times evaluated. Silages subjected to longer fermentation times showed lower levels of NDF, ADF and CP, lower gas losses, and lower $\mathrm{pH}$ values over 5 days of exposure to air. As the storage periods were increased, there were increases in the content of soluble protein and losses by effluents, as well as in the number of hours required to reach the maximum temperature and break the aerobic stability of the silages. Coarse grind silages subjected to 56 days of storage showed better chemical composition, lower LAB and mold counts, and less susceptibility to microbial degradation when exposed to air.

\section{Acknowledgments}

We are grateful to CAPES for the granting of the scholarship of the Master's Program in Health and Animal Production, from Unoesc Campus Xanxerê, SC. We thank Frigorífico Arvoredo $^{\circledR}$ for the availability of supply of rumen inoculum for the analysis 
of in vitro digestibility. We also thank the microbiology laboratory of UDESC Pinhalzinho for their willingness to carry out the microbiological analyses. Finally, we thank to animal science students Gabriel Rossato, Edemar Aniecevski, Janine Bachamann, and Tainara Basso, as well as the lab technician Samara Pozzan for the valuable help in compacting the silage in the mini-silos.

\section{References}

Association of Official Analytical Chemists (1991). Official methods of analysis. (15a ed.). Washington DC.

Arcari, M. A., Martins, C. M. de M. R., Tomazi, T., \& Santos, M. V. dos. (2016). Efeito do tempo de ensilagem do milho moído hidratado sobre a composição da silagem e degradabilidade in situ do amido. Brazilian Journal of Veterinary Research and Animal Science, 53(1), 60-71. doi: 10.11606/issn.1678-4456.v53i1 p60-71

Bernardes, T. F., \& Chizzotti, F. H. M. (2012). Technological innovations in silage production and utilization. Revista Brasileira de Saude e Producao Animal, 13(3), 629-641. doi: 10.1590/S1519-994 02012000300004

Bitencourt, L. L. (2012). Substituição de milho moido por milho reidratado e ensilado ou melaço de soja em vacas leiteiras. Tese de doutorado, Universidade Federal de Lavras, Lavras, MG, Brasil.

Carvalho,P.deA.(2014).Influênciadogenótipoe maturidade na diversidade microbiológica em milho grão para silagem. Dissertação de mestrado, Universidade de São Paulo, Piracicaba, SP, Brasil.
Denardin, C. C., \& Silva, L. P. da. (2009). Starch granules structure and its regards with physicochemical properties. Ciencia Rural, 39(3), 945-954. doi: 10.1590/S01 03-84782009005000003

Ferraretto, L. F., Crump, P. M., \& Shaver, R. D. (2013). Effect of cereal grain type and corn grain harvesting and processing methods on intake, digestion, and milk production by dairy cows through a meta-analysis. Journal of Dairy Science, 96(1), 533-550. doi: 10.3168/jds.2012-5932

Ferraretto, L. F., Taysom, K., Taysom, D. M., Shaver, R. D., \& Hoffman, P. C. (2014). Relationships between dry matter content, ensiling, ammonia-nitrogen, and ruminal in vitro starch digestibility in high-moisture corn samples. Journal of Dairy Science, 97(5), 3221-3227. doi: 10.3168/jds.20137680

Firkins, J. L., Eastridge, M. L., St-Pierre, N. R., \& Noftsger, S. M. (2001). Effects of grain variability and processing on starch utilization by lactating dairy cattle. Journal of Animal Science, 79(E-Suppl.), E218. doi: 10.2527/jas2001.79e-supple218x

Fredin, S. M., Ferraretto, L. F., Akins, M. S., Bertics, S. J., \& Shaver, R. D. (2015). Effects of corn-based diet starch content and corn particle size on lactation performance, digestibility, and bacterial protein flow in dairy cows. Journal of Dairy Science, 98(1), 541-553. doi: 10.3168/jds.2014-8502

Holden, L. A. (1999). Comparison of methods of in vitro dry matter digestibility for ten feeds. Journal of Dairy Science, 82(8), 1791-1794. doi: 10.3168/jds.S0022-0302 (99)75409-3 
Hwanhlem, N., Ivanova, T., Haertlé, T., Jaffrès, E., \& Dousset, X. (2017). Inhibition of food-spoilage and foodborne pathogenic bacteria by a nisin Z-producing Lactococcus lactis subsp. lactis KT2W2L. LWT - Food Science and Technology, 82, 170-175. doi: 10.1016/j.Iwt.2017.04.052

Instrução Normativa $n^{\circ} 62$, de 26 de agosto de 2003. Ministério da Agricultura, Pecuária e Abastecimento Diário Oficial da União. Brasília, 18 de setembro de 2003.

Jobim, C. C., Nussio, L. G., Reis, R. A., \& Schmidt, P. (2007). Avanços metodológicos na avaliação da qualidade da forragem conservada. Revista Brasileira de Zootecnia, 36(Suppl.), 101-119. doi: 10. 1590/s1516-35982007001000013

Junges, D. (2014). Tempo de armazenamento e manejo do painel no valor nutritivo de silagens de milho. Tese de doutorado, Universidade de São Paulo, Piracicaba, SP, Brasil.

Kung, L., Schmidt, R. J., Ebling, T. E., \& Hu, W. (2007). The effect of Lactobacillus buchneri 40788 on the fermentation and aerobic stability of ground and whole highmoisture corn. Journal of Dairy Science, 90(5), 2309-2314. doi: 10.3168/jds.2006713

Kung, L., Windle, M. C., \& Walker, N. (2014). The effect of an exogenous protease on the fermentation and nutritive value of highmoisture corn. Journal of Dairy Science, 97(3), 1707-1712. doi: 10.3168/jds. 20137469

Licitra, G., Hernandez, T. M., \& Soest, P. J. Van. (1996). Standardization of procedures for nitrogen fractionation of ruminant feeds. Animal Feed Science and Technology,
57, 347-358. doi: 10.1016/0377-8401 (95)00837-3

Mcallister, T. A., Rode, M., Major, D. J., Cheng, K., \& Smith, J. G. B. (1990). Effect of ruminal microbial colonization on cereal grain digestion. Canadá Journal of Animal Science, 579, 571-579.

Mendes, I.A.P.(2013). Consumo, digestibilidade, produção e composição do leite de vacas alimentadas com silagem de grão de milho moído reidratado substituindo milho seco moído do concentrado. Dissertação de mestrado, Universidade Federal de Minas Gerais, Belo Horizonte, MG, Brasil.

Neumann, M., Mühlbach, P. R. F., Nörnberg, J. L., Ost, P. R., Restle, J., Sandini, I. E., \& Romano, M. A. (2007). Características da fermentação da silagem obtida em diferentes tipos de silos sob efeito do tamanho de partícula e da altura de colheita das plantas de milho. Ciência Rural, 37(3), 847-854. doi: 10.1590/s010384782007000300038

Owens, F. (2015). Corn grain processing and digestion. Minnesota Nutrition Conference, 1-21.

Pereira, M. L. R. (2012). Degradabilidade ruminal in vitro de grão reidratado e ensilado de milho e sorgo com diferentes granulometrias. Dissertação de mestrado, Universidade Federal de Goiás, Goiânia, GO, Brasil. Retrieved from https:// repositorio.bc.ufg.br/tede/bitstream/ tde/869/1/DissertacaoMarcela L R Pereira.pdf

Reis, R. B., Moura, A. M., \& Malacco, V. M. R. (2014). Processamento de amido do concentrado para vacas em pastejo. Anais do Simpósio Internacional Em Formulação 
de Dietas Para Gado Leiteiro, Lavras, MG, Brasil.

Rezende, A. V., Rabelo, C. H. S., Veiga, R. M., Andrade, L. P., Härter, C. J., Rabelo, F. H. S.,... Reis, R. A. (2014). Rehydration of corn grain with acid whey improves the silage quality. Animal Feed Science and Technology, 197, 213-221. doi: 10.1016/j. anifeedsci.2014.07.009

Saylor, B. A., Casale, F., Sultana, H., \& Ferraretto, L. F. (2019). Effect of microbial inoculation and particle size on fermentation profile, aerobic stability, and ruminal in situ starch degradation of high-moisture corn ensiled for a short period. Journal of Dairy Science, 103(1), 379-395. doi: 10.3168/ jds.2019-16831

Silva, B. de C. (2018). Efeito da ensilagem de grãos de milho e sorgo reidratados sobre os locais de digestão e estimação da digestibilidade in vivo através de procedimentos de incubação ruminal in situ e in vitro em bovinos Nelore. Dissertação de Mestrado, Universidade Federal de Viçosa, Viçosa, MG, Brasil.
Silva, C. M., Amaral, P. N. C. do, Baggio, R. A., Tubin, J. S. B., Conte, R. A., Dal Pivo, J. C.,... Paiano, D. (2016). Estabilidade de silagens de grãos úmidos de milho e milho reidratado. Revista Brasileira de Saude e Producao Animal, 17(3), 331-343. doi: 10.1590/S1519-99402016000300001

Tres, T. T., Jobim, C. C., Rossi, R. M., Silva, M. S. da, \& Poppi, E. C. (2014). Silagem de grãos de milho, com adição de soja: Estabilidade aeróbia e desempenho de vacas leiteiras. Revista Brasileira de Saude e Producao Animal, 15(1), 248-260. doi: 10.1590/ S1519-99402014000100002

Van Soest, P. J., Robertson, J. B., \& Lewis, B. A. (1991). Methods for dietary fiber, neutral detergent fiber, and nonstarch polysaccharides in relation to animal nutrition. Journal of Dairy Science, 74(10), 3583-3597. doi: 10.3168/jds.S0022-0302 (91)78551-2

Wilkinson, J. M., \& Davies, D. R. (2013). The aerobic stability of silage: key findings and recent developments. Grass and Forage Science, 68(1), 1-19. doi: 10.1111/j.13652494.2012.00891.x 